\title{
Social and Musical Impact on Cyprus as British Colony: A Historic Overview
}

\begin{abstract}
This paper is seeking to address the question of how the wider socioeconomic capitalisation process during British colonialism affected musical life in the case of Cyprus. The main sources for research are products of the island's Greeklanguage press of the first half of the $20^{\text {th }}$ century as well as literature related to the socio-economic framework of the same period. From the colonial period onwards, Cypriot culture accepted the public concert as the dominant means for presenting music and developed a stable institutional foundation for Western art music together with its commercial paraphernalia including musical instruments and sound devices. Considering commodification as one of the initial characteristics of the capitalist way of production, this paper will seek to identify the ways in which music activity in colonial Cyprus had adapted to the notion of commercial advantage, thus setting a solid infrastructure which allowed it to enter the capitalist exchange system in a commodity form.
\end{abstract}

Keywords: Cyprus, music, British colonialism, capitalism, commodification

\section{Introduction}

Many post-colonial studies in the fields of sociology and anthropology of music have, in the recent past, been concerned with the impact of British (and other) colonialism on local cultures, sharing common or similar observations about westernisation of colonised societies and their musics. As many of these studies demonstrated, the „civilising mission“ which was undertaken by the British Empire over its colonies was usually ,naturalised“ by both colonised and colonisers through social integration so as to be considered as an „unquestionably good" phenomenon and the only road towards progress (Clayton \& Zon 2007 and Born \& Hesmondhalgh 2000). However, the fact that the process of westernisation was a part of a wider colonial campaign that pursued to establish capitalism as the modern socio-economic form that every civilised country should adopt being considered again as synonym to progress, 
remained mostly unremarked or given relatively little attention by literature and so are questions about evolving commodification and its effects on cultural production such as music.

The arrival of the British on Cyprus in 1878 signalled the start of a long transition from a traditional society to a European capitalist state. A number of modernising reforms such as the ,property of land" reform and a modified tax collection system gave political power to the British administration. Apart from fulfilling its strategic aims on Cyprus, which included its use as a military depot, Great Britain made development of the colony through the capitalisation of its economy a priority. This set in motion considerable changes in the social, economic and political life of the island, such as the economic decline of the peasantry, the rural population's migration to urban centres, the creation of a local middle class with characteristics of a bourgeoisie, a new system of local political representation, the development of trade and creation of new market demands, the rise of Greek nationalism, and the emergence of the local labour movement. This transition to capitalism affected the musical activity of the island during the same period, leading gradually to its commodification.

\section{The appearance of the notion of the public concert ${ }^{1}$ on Cyprus}

When Great Britain assumed control of Cyprus in 1878, two main categories of musical culture were established among the Cypriot population. The relatively few extant sources referring to Greek-Cypriot music during the Ottoman period show that Greek Orthodox ecclesiastical music was performed in churches and monasteries, and that traditional music was performed in a variety of secular settings. European classical music, on the other hand, only started to gain ground on the island under the influence of British colonialism. During the early stages of colonial rule, European music was performed mainly by non-Cypriots at private social evenings in the homes of British dignitaries. Among the musicians were British government officials and a number of musicians who arrived in Cyprus from Smyrna, Istanbul, Italy, Germany, Greece, and Egypt.

The notion of offering a public concert to any who could afford the ticket, appeared on Cyprus in the circles of the small British community shortly after their arrival on the island. The first mention of a European music concert in Cyprus appears in Neon Kition one year after the arrival of the British. According to Olmsted (2002), in England public concert grew out of an evolving capitalism during the seventeenth century, when music started adopting forms that allowed it to enter the rapidly established capitalist exchange system and therefore contribute to the production of

1 Public concert is the performance of instrumental or vocal music for an audience whose attendance is restricted only to the payment of admission on a per-event basis (Olmsted 2002: 109). 
surplus value (Olmsted 2002; see also Marx (1984 [1861-63]: 145-329). The notion of music commodity was very innovative for the Cypriot society of the late nineteenth century, for until that time local music had remained for the most part traditional in its organisation. The Cypriot fiddler, laouto player or folk singer functioned as merchants who sold their musical services to social events such as wedding celebrations, local festivals called 'panegyria' and family gatherings, a practice that although sometimes contained merchandise characteristics, it had not adopted the major characteristics of capitalist commodification ${ }^{2}$ (Attali 1985 [1977]; Taylor 2007). On the other hand, the newly introduced public concert carried with it modern ideas of the already established European culture industry, in which music was yet another commodity. On Cyprus the introduction of classical concerts set the foundation for, in Adorno's words, music's separation from its ,religious and ceremonial function of earlier practice“ (Adorno 2002: 128), a traditional role that is well described in a number of local folklore narratives that exist. According to the same author, this made music ,abstractly exchangeable“ and „had therefore torn [it] asunder for the immediacy of use" (Adorno 2002: 128-129). The first Cypriots who were introduced to this new concept of presenting music were mainly those from the traditional local urban elite who had been placed in administrative positions by the colonial government.

A few years after the arrival of the British, the urban population of Cyprus began to increase with the migration of rural populations, who had previously been occupied in agrarian economy, from their villages to the towns. The new social class that subsequently arose inevitably triggered a reconfiguration of status among the members of the traditional local elite. The new phenomenon of the public concert that mainly addressed the urban market, was an 'object' for consumption that could make evident the economic standing of each social class so as to differentiate the elite from the newly created middle class.

Both socio-economic and cultural transformations were pursued as parts of the „civilizing mission“ of a wider British imperial ideology in creating and maintaining the capitalist economy in their colonies. The introduction of western musical practices such as the public concert with preference to western art music, was part of the British „civilising mission“ and was clearly reinforced by the local urban elite in newspapers" reports. Called by the press „the select,“" or „distinguished personalities“ (Salpinx, 16 April 1904), members of the traditional elite who could afford to attend public concerts

\footnotetext{
2 A musician who sells his/her music is a merchant (consequently an unproductive worker), not someone producing value and therefore not participating in the accumulation of capital. If a musician joins forces with a capitalist entrepreneur such as a concert organiser, music institution, publishing, record business and musical instruments production and sale then he/she contributes to the production of surplus value (he/she becomes a productive worker), thus his/her function is characterised as capitalist. Regarding productive and unproductive labour in capitalism see Marx (1984 [1861-63]: 145-329) and also (1993 [1857-8]: 305).
} 
marked their social status as separate from that of the ordinary middle class. Newspaper Kyprios, exemplifies this observation in its issue on 31 March 1900, by mentioning the presence of „,...) many of our (Cypriot) distinguished people [who] filled the boxes and the parterre" in an Italian melodrama (opera). Looking at the press of the time there is a considerable number of similar to the above publications which demonstrate a cultural manifestation of the upper-class socioeconomic superiority compared to the rest of the population thus a means to legitimise the existing and developing „social and income inequality“ (Constantine 1986: 193).

\section{The triumph of music westernisation}

Continuing the trend that emerged with the arrival of the British on the island, references to Western European genres and practices increased and dominated coverage of music in the urban press in the 1930s and 1940s. They included announcements of classical concerts and classical music lessons, reports about the foundation and operation of music schools as well as advertisements for instruments, radiophone and gramophone sales.

The dissemination of 'superior' Western culture, including Western art music was a common practice in British colonies including Cyprus, which accompanied Britain's general economic policy of the late 1920s, known as the ,imperial solution“ (Constantine 1986: 195). The economic depression that tremendously increased the „unemployment rates" and ,the need to protect the threatened sterling by reducing the dollar gap caused by trade and debts to the USA was (...) additional incentive[s] to trade with sterling areas especially in the Empire" (Constantine 1986: 195). Under these circumstances, in 1926 the Empire Marketing Board was established suggesting that imperial ideology was a central preoccupation of the British colonial power. According to Severis (2006):

\footnotetext{
„(...) the Empire Marketing Board had a responsibility to spread the idea of imperialism and the concept of the Empire as beneficent. [This institution] made extensive use of photographs, postcards, films and posters in order to help to link Britain more closely with her Empire and the dominions, making her less vulnerable to foreign competition, to encourage trade within the Empire (...) (p. 201).“
}

In addition, several economic pressure groups with imperial interests appeared between the years 1916 and 1930 such as the British Empire Producers Organisation, the British Commonwealth Union, the Empire Resources Development Committee, the Empire Development Parliamentary Committee, the Empire Development Union, the Empire Industries Association and the Empire Economic Union (Constantine 1986: 194). 
The main economic aim of British imperial policy of the time was to find and develop new markets for the Empire's industry that would replace lost European markets with further development of trade with overseas countries, especially those within the British Empire (Constantine 1986: 195-195). This imperial policy was mainly based on Adam Smith and Robert Nelson's Western economic theory of the eighteenth century that ,elaborated the term market into a concept denoting an abstract space where supply and demand meet and find equilibrium through the pricing of commodities or services" (Laing 2003: 311). Based on Western economic theory, British colonial power set as its main aim to increase the demand of the markets that would be supplied by the British industry by creating new consumer needs, in the form of commodities, including musical needs.

Britain's Mediterranean and Middle Eastern colonies thus constituted fertile ground in which Western art music genres and practices could grow and spread, contributing both to the imperial economy and the triumph of cultural westernisation in the East. The development of colonial music markets that involved „consumers of musical goods and services, employers of musician's labour power and/or business that use music" (Laing 2003: 309) had been the case in many British colonies in the east (Baily 1988; Beckles Wilson 2013).

The beginning of commodification of musical activity in urban areas is well reflected in the foundation of the first 'philharmoniki etaireia' (wind band company), named Orfeas (1890), traced to synonymous musical institutions that founded in modern Greece (based on the dominant model of the $19^{\text {th }}$ century European education), such as 'philharmoniki etaireia' of Corfu (1840). Unlike the larger Greek institutions that offered a number of instrumental lessons, music theory and possibilities of participation in variant music ensembles (most commonly in wind bands), Cypriot type's 'philharmoniki etaireia' offered only wind lessons for the exclusive needs of the performances of a local wind band that took place on a regular base in public locations (Salpinx, 19 May 1890). 'Philharmoniki etaireia' Orfeas appeared in Larnaca, which due to its harbour (Famagusta Port) was considered as ,the centre of the trade" (Alitheia, 20 July 1881) from where modern culture was imported and disseminated. In the context of a rapid trade development it is hardly surprising that the first local wind bands were labelled as companies not only tracing to similar Greek examples, but also identifying themselves as profit-making organisations. Other profit-making musical associations were „Musical Company“ founded in 1920s and „Musical Companionship“ and „Mozart" in 1930s and 1940s, the impresarios of which undertook the organisation of musical events and the offering of instrumental training integrating the rules of European capitalist production. 


\section{The foundation of music schools and the promotion of concerts of Western European music}

Considering the economic situation of the majority of the Cypriot people, the creation of a market for Western music in Cyprus was not an easy task. The first requirement was the cultivation of Western music tastes among the 'uneducated' Cypriot people by providing Western music education. The spread of music education in early nineteenth-century Europe was exported by British colonisation to a broad range of its eastern colonies such as Cyprus, Egypt, India and Palestine. Highlighting the use of education within British cultural imperialism, Constantine (1986) asserts that, „(...) using teachers and schools for propaganda work was a particularly appropriate way of disseminating a dominant imperial ideology: it was obviously less concerned with influencing the imperial consumers of today than with moulding the minds of the imperial citizens and consumers of tomorrow" (p. 214).

The first action in the field of music education that was taken by the British government in Cyprus was the establishment of a School of Music in 1927, the first in the history of the island. This governmental music school offered mainly Western musical studies and it operated under the aegis of governor Ronald Storrs. It is noteworthy that Storrs (1937) admits, in his writings about Cyprus, that this governmental music school ,[was] established to create, rather than to supply a demand“ (p. 515). The Cyprus School of Music offered piano, guitar, mandolin and singing lessons. In the beginning, thirty-nine students were enrolled and after three months they gave their first student concert (Christodoulidou 2008: 243). From 1928 on, interest and standards were maintained by affiliation to Trinity College of Music, in London, which conducted annual examinations (Storrs 1937: 516). However, according to governor Storrs (1937), the operation of the music school was not considered entirely successful since local demand for Western music ranged from limited to non-existent. Moreover, the music school appeared to face economic problems due to the fact that the students could not afford to pay the fees and had to pay them long overdue (Chronos, 4 July 1927).

The foundation of the Cyprus School of Music at the initiative of the colonial government rather the demand of Cypriot society, as well as the fact that the students faced difficulties paying the school's fees, were reflected in a sarcastic poem entitled 'Odeion (Music School)' published in Nea Laiki and was attributed to someone called Dervis. The poem asserts that under the current economic circumstances, the music school was not a social need of the Cypriot people and therefore should not be a priority for its government, which should solve many other problems first: 


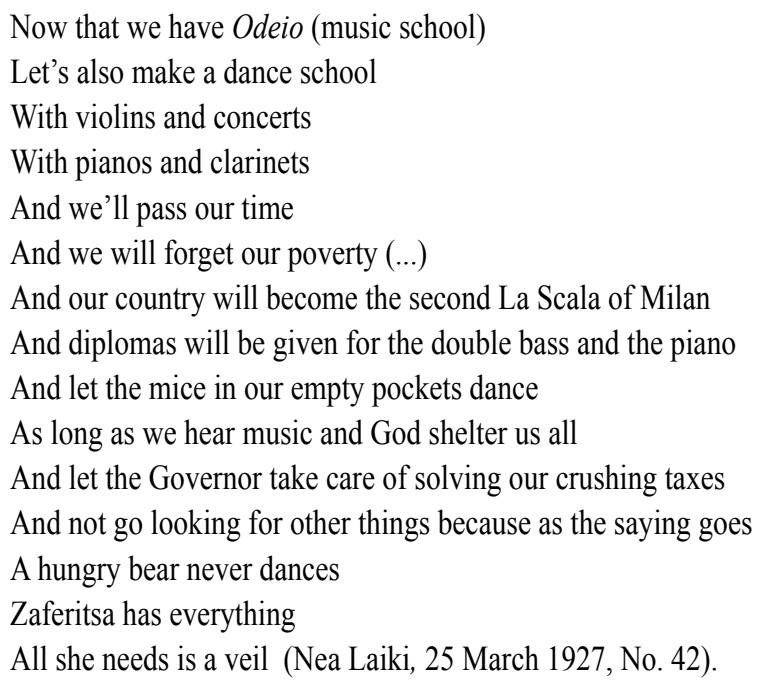

From 1926 until 1931, apart from the governmental School of Music in Nicosia, the press heavily advertised the opening of local private music schools in other Cypriot towns or announced private lessons for particular instruments including the piano, the violin, the mandolin and the guitar. Despite the sporadic inclusion of some folk instruments and Byzantine chant instruction, this development contributed mainly to the reinforcement of the cultivation of Western European musical taste in Cypriots and also enhanced the gradual establishment of the domination of Western-type musical institutions. Announcements in the press that referred to private music instruction usually included a great deal of information about the qualifications of the teacher, the lessons he/she offered, and the fees (Nea Laiki, 7 October 1927, No. 70).

The further development of instrumental training in Cypriot towns was soon supported by the creation of a first market of musical instruments, the importation of which began in the first decade of the twentieth century, facilitated by the general development of the transport systems. The newly imported musical commodities soon occupied a place in the developing advertising practice of newspapers. The first report on the importation of musical instruments appeared in the press in 1904 and advertised Boisselot pianos: „80 Boisselot pianos in Cyprus. Representatives F. Kolakides and Son" (Salpinx, 7 February 1904). This was soon followed by an advert for the first piano tuner, a Mr Edward J. S. Papasian (Salpinx, 24 April 1904). A few years later other types of pianos appeared on the Cypriot market. In 1909, the press advertised Otto \& Carl Philipp pianos by the importer Mr M. I. Tziapouras (Salpinx, 15 January 1909), while a little later it advertised W. Hartmann pianos by the importer Mr G. M. I. Efthyvoulou (Salpinx, 18 September 1909). As for string instruments, which enabled the formation of string ensembles in the towns, the press announced in 1908 the first Cypriot maker of string instruments: „Formerly working in Athens for many years (...) the Cypriot 
instrument maker Mr Kyprianos Evangelides, whose instruments have been amazingly disseminated (...) has decided to settle in Limassol. He undertakes the production of every type of string instrument" (Salpinx, 19 April 1908 and 28 October 1910).

In addition to the foundation of public and private music schools and the instrument advertisements, the flood of announcements and reviews of European music performances illustrate the triumph of music westernisation in urban Cypriot areas. A considerable percentage of the musical items that appeared in the urban Cypriot press of the time were announcements and reports of classical music concerts. These reports usually described events and their participant musicians with flattering comments, thus strongly promoting attendance by Cypriots. The increase in the number of these announcements in the urban press compared to the first two decades of the $20^{\text {th }}$ century testify to the intensification of capitalising and westernising trends amongst the local high bourgeoisie and upper classes.

A few articles record the financial contribution made to these events by the British government, demonstrating its role in encouraging their colonial subjects to „change their [cultural] habits“(Constantine 1986: 200), including their musical habits, and adapt to the needs of European industries. This cultural policy that operated in parallel with the general imperial orientation had a range of political and ideological motivations including the creation of cultural connections that could bring profits to British industry, and consequently the British economy. The following example appeared in Nea Laiki with the title „Recital of Ms Lu Lumida“ and reviewed a classical concert given in 1927 by a famous German singer in Nicosia. The reference to the contribution of the British governor of Cyprus in its first line demonstrates his social and financial role in promoting interest in such events.

„On Saturday, at the Magic Palace under the patronage A. E. (His Excellency) the Governor a recital will be given by the much-anticipated famous Contralto of Berlin and Dresden Mrs. Lu Lumida. Nicosia for the first time has the great fortune to hear one of the most famous vocalists of Germany, who has sung with extraordinary skill and strength works by Wagner, Grieg, Saint-Saëns, Schumann, Brahms etc. The select audience with the prominent presence of the Governor energetically acclaimed the genuinely magnificent artist (21 January 1927, No. 33).“

\section{The dissemination of radios, gramophones and discs in the Cypriot market}

The end of the nineteenth century was marked by a remarkable development and extension of the range of media and communication that culminated in the beginning of the twentieth century. In 1922, the British Radio was formed and rapidly established as a mass medium. Moreover, in 1926 the British Broadcasting Corporation was established and started transmitting to many British colonies including the 
Mediterranean and Middle East. Having the control of airwaves, the British Empire used this new invention considerably for the purposes of various social, political and cultural agendas, thus making radios a new means of interfering in local discourses (Baily 1997; Beckles Wilson 2013).

In 1928, the modern technological development, the radiophone, was dispatched to Cyprus from Europe, later becoming a contributing factor in reinforcing the capitalising 'mission' of British colonialism. The new device that was unknown and odd to the local society attracted the attention of the urban press. Indicative of the dissemination of radio in Cypriot society is the fact that notices regarding radio programmes achieved a permanent place in the local newspapers at that time. When one reviews these radio columns, it is noticeable that they mainly refer to programmes broadcast from London, indicating how the British Empire employed this new medium to extend its political and cultural influence over its colonies. As well exemplified by Beckles Willson (2013) in the case of Palestine, the radio was a useful device in the hands of the British colonial government with which it interfered in the local socio-political and cultural discourse. Various radio programmes by the BBC Empire service addressed different regions governed by the Empire, which were processed in different languages because of the ethnic diversity of the listeners of each time. Like other radio programmes that addressed local populations in Palestine, India and Malta, the so-called 'Cypriot programme' (launched in 1942 and broadcast every Wednesday and Sunday), claimed an educative role for the local population that covered social, political and cultural aspects. Western art music as part of the cultural education of colonised subjects of the British Empire was usually preceded by and followed these local programmes. At the same time, by promoting Western industrial goods and services in colonial markets, radio broadcasts from Britain reinforced the process of establishing capitalist relations through commercialised culture.

Radio columns published in Cypriot newspapers indicate that western art music was also broadcast during shows dedicated to music, allowing it to dominate radio airtime. Published radio schedules record that occurrences of European classical music outnumbered those of other musical styles. This may be seen in the titles of musical programmes that appeared in the newspapers: Music Ensemble, Piano Music, Recital, Music Interlude, Handel, Mozart, Haydn, London Madrigal Choir, Viennese music, Classical German Dances, Beethoven Sonatas, Symphonic Orchestra, Music from Operas and Operettas, and Violoncello Concerts. Other broadcasted music of European origin listed in Cypriot newspapers included dance music, folk music, old English songs, light orchestral music, recitals by artists of the Empire, military bands, National Anthems, Welsh music and Irish music (Kypriakos Fylax, 13 December 1936; 20 April 1937; 1 June 1938; 21 May 1938; 20 July 1938; Eleftheria, 6 May 
1937; 4 February 1938; 23 April 1938; 11 October 1938; 15 December 1938; 18 February 1939; Proini, 19 May 1934; 23 February 1937; 27 February 1937). As in Cyprus, in colonies such as India, Afghanistan and Palestine, Western music was promoted by the Western culture industry and largely perceived by local populations as a kind of technological progress that led to a 'musical renaissance' (Clayton and Bennett 2007). Britain's orientalist approach, coming from both local and foreign agents, reinforced the capitalist development of the colonies as a process that aimed to make them more and more profitable for the British economy.

Apart from the enthusiastic reports regarding the newly introduced radio device, the promotion of gramophones as well as discs increased in the urban press. According to Christodoulidou (2008), during the summer of 1927, gramophones together with music discs invaded the life of the capital of Cyprus, Nicosia: „(...) the gramophones and [record] discs constitute this season's new trend and goods that all respectable houses wish to acquire. Hence the press was full of advertisements for different kinds of gramophones that flooded the markets with origins from countries such as Great Britain and the USA“" (p. 244).

As shown in the press, the phenomenon of commercial advertisements that appeared together with the modernisation and dissemination of capitalist economic relations played a significant role in creating and increasing demand for the newly introduced sound devices in the Cypriot market. Many newspapers became flooded by advertisements that promoted radios and gramophones, a practice that proved fruitful for the further dissemination of these sound products. The Paratiritis issue of June 1930 includes a large advertisement for radios that Philips presented in a form that demonstrates an older stage of the commercial practice of advertising. In capital letters there is the phrase „Obtain Philips Radios“ and also the subtitle „Grand Prize in the International Exhibition of London." It is remarkable that at the top of the advertisement it addresses two categories of people obviously determining its target group. These were the „Music-lovers: For listening to the European concerts“ and the „Teachers: For attending the international speeches“ (14 June 1930).

As shown by many advertisements, the British suppliers of gramophones and radios seem to dominate the Cypriot market. Maxitone gramophones and radios that were constructed by Lugton and Co. in London appeared in a large number of newspaper promotions (Paratiritis, 27 January 1930). In addition, the British brand Amplion was also advertised a great deal in the press in some very flattering paragraphs: „The clear and free of atmospheric static music reception and speech is the main reason that Amplion has been given first place and is recognised as THE BEST IN THE WORLD (...). With the value of a gramophone you [can] buy a radio“" (Chronos, 27 January 1930). 


\section{Conclusion}

By the beginning of the $20^{\text {th }}$ century it becomes apparent that the introduction and gradual development of ,capitalism as a social form [had] profoundly shap[ed] people's relationships to each other and their relationships to cultural forms such as music"(Taylor 2016: 1). Together with the introduction of the notion of public concert, other components of western music industry had also introduced to Cypriot urban society in an effort to create new market demands. On Cyprus, Western art music started gaining ground only among the elite, after the arrival of the British. The market for Western art music goods and services - that was pursued in Eastern colonies - was therefore a new arena with expanding potential that would increasingly prove beneficial for Great Britain's suffering economy. The creation of demand for Western music products was also fostered by the local urban elite, who showed great hospitability for cultural developments coming from Europe as superior to local. In fact, the „civilising mission" of the British Empire was duplicated by the Cypriot urban press that carried extensive coverage of European art music genres and practices, thus demonstrating that Western music was not only an artefact of British colonial imposition but also a means of self-definition of Cypriot bourgeoisie. By the first decade of the twentieth century, the nascent capitalist infrastructure of music performance was reinforced by the importation of music instruments, radiophones, gramophones and music discs. The economic development fostered by the British colonial government had set in motion the mechanism through which music activity could be used for commercial advantage by an increasingly urbanised consumer society. Musical events in the towns thereafter developed into separate, independent activities requiring an entrance fee for the public and taking place in specially arranged venues, such as a theatre, a concert hall, or even a popular nightclub with an oriental tint. The resultant commercial musical culture formed by the domination of European classical musical instruction in urban society, as well as by the sales of instruments and other musical equipment were all significant parts included in the wider process towards Cyprus' capitalisation.

The economic crisis that followed the onset of the First World War intensified the colonial administration's drive to capitalise the Cypriot economy through the socalled British „Imperial Solution,“ which aimed to increase the demand for Western industrial products in the colonies. The wave of peasants who, as a consequence of the economic crisis, were forced to migrate to urban areas in search of work were also potential consumers of new commodities that were enthusiastically promoted by the local press thus further encouraging the commodification of local musical practices. The foundation of the first Governmental School of Music together with many other local private music schools were heralded in advertisements aiming to create a new local demand rather than supply an already existing one. Although this endeavour initially 
proved rather unsuccessful on Cyprus, since the economic recession that continued until 1945 affected the majority of the Cypriot population, thus preventing wide local consumption of new musical services and products, it set the groundwork for the later construction and domination of classical music education. By the end of the Second World War, Western musical industry became the dominant force in Cypriot music through publishing, mass entertainment, musical instruction, and sales of discs, musical instruments and record players. The capitalisation of music on Cyprus thus mirrored its progress in other British colonies including Egypt, India and Malta (see Storrs 1937; and also Baker 1998).

\section{REFERENCES:}

1. Adorno, Theodor W. 2002 [1931]. „Why is the New Art so Hard to Understand?“ in Richard Leppert (ed.) Essays on Music. Theodor W. Adorno. Berkeley: University of California Press, pp.127-134.

2. Attali, Jacques. 1985 [1977]. Noise. The Political Economy of Music. Minneapolis: University of Minnesota Press.

3. Baily, John. 1988. Music of Afghanistan: Professional Musicians in the City of Herat, Vol. II. Cambridge: Cambridge University Press.

4. Baily, John. 1997. „The Role of Music in the Creation of an Afghan National Identity, 192373" in Martin Stokes (ed.) Ethnicity, Identity and Music; The Musical Construction of Place. Oxford: Berg, pp.45-60.

5. Baker, Colin. 1998. Retreat from Empire: Sir Robert Armitage in Africa and Cyprus. London: Tauris Academic Studies.

6. Beckles Willson, Rachel. 2013. Orientalism and Musical Mission: Palestine and the West. Cambridge: Cambridge University Press.

7. Born, Georgina \& David Hesmondhalgh (eds.). 2000. Western Music and its Others; Difference, Representation, and Appropriation in Music. London: University of California Press.

8. Christodoulidou, Cristina-Evelin. 2008. „Anglokratia kai Dekaetia tou 1960: Lefkosia (British Colonialism and the Decade of 1960s: Nicosia)“, in Marina Vrionidou-Yiangou (ed.) En Chordais kai Organois. Diaskedasi kai Psihagogia stin Kypro apo tin Arhaiotita mehri tin Anexartisia (With Pomp and Circumstance: Amusement and Entertainment in Cyprus from Antiquity until Independence). Nicosia: Politistiko Kentro Trapezas Marfin Laiki, pp. 208-265.

9. Clayton, Martin and Bennett Zon. 2007. Music and Orientalism in the British Empire, 1780s-1940s. Portrayal of the East. Aldershot: Ashgate.

10. Constantine, Stephen. 1986. „Bringing the Empire Alive: The Empire Marketing Board and Imperial Propaganda, 1926-33“, in John M. MacKenzie (ed.) Imperialism and Popular Culture. Manchester: Manchester University Press.

11. Laing, Dave. 2003. „Music and the Market. The Economics of Music in the Modern World,“ in Martin Clayton, Trevor Herbert and Richard Middleton (eds.) The Cultural Study of Music. A Critical Introduction. New York and London: Routledge.

12. Marx, Karl. 1993 [1857-8]. The Grundrisse. London: Penguin Classics 
13. Marx, Karl. 1984 [1861-63]. Theories yia tin iperaxia [Theories of the Surplus Value]. Athens: Sygchroni Epochi

14. Olmsted, Anthony A. 2002. „The Capitalization of Musical Production: The Conceptual and Spatial Development of London's Public Concerts, 1660-1750, “in Regula Burckhardt Qureshi (ed.) Music and Marx. Ideas, Practice, Politics. New York: Routledge, pp. 106-138.

15. Severis, Rita C. 2006. „Travelling Artists in Cyprus: Art, Identity and Politics,“ in Hubert Faustmann and Nicos Peristianis (eds.) Britain in Cyprus. Colonialism and Post-Colonialism 1878-2006. Manheim: Bibliopolis. pp. 381-412.

16. Storrs, Sir Ronald. 1937. The Memoirs of Sir Ronald Storrs. New York: G. P. Putnam's Sons.

17. Taylor, Timothy. 2007. „The Commodification of Music at the Dawn of the Era of 'Mechanical Music'“. Ethnomusicology, Vol. 51, No. 2, pp. 281-305.

18. Taylor, Timothy. 2016. Music and Capitalism. A History of the Present. Chicago: The University of Chicago Press.

\section{PRIMARY SOURCES: NEWSPAPERS}

Alitheia, 20 July 1881

Chronos, 27 January 1930

Chronos, 4 July 1927

Eleftheria, 11 October 1938

Eleftheria, 15 December 1938

Eleftheria, 18 February 1939

Eleftheria, 23 April 1938

Eleftheria, 4 February 1938

Eleftheria, 6 May 1937

Kypriakos Fylax, 20 April 1937

Kypriakos Fylax, 20 July 1938

Kypriakos Fylax, 21 May 1938

Kypriakos Fylax, 13 December 1936

Kypriaos Fylax, 1 June 1938

Kyprios, 31 March1900

Nea Laiki, 21 January 1927, No. 33

Nea Laiki, 25 March 1927, No. 42

Nea Laiki, 7 October 1927, No. 70

Paratiritis, 14 June 1930

Paratiritis, 27 January 1930

Proini, 19 May 1934

Proini, 23 February 1937

Proini, 27 February 1937

Salpinx, 16 April 1904

Salpinx, 15 January 1909

Salpinx, 18 September 1909

Salpinx, 19 April 1908 
Salpinx, 28 October 1910

Salpinx, 19 May 1890

Salpinx, 24 April 1904

Salpinx, 7 February 1904

\section{Društveni i muzički uticaj na Kipru kao britanskoj koloniji: istorijski pregled}

Apstrakt: Ovaj rad nastoji da razmotri pitanje kako je širi proces društveno-ekonomske kapitalizacije tokom britanskog kolonijalizma uticao na muzički život Kipra. Glavni izvori za istraživanje su napisi iz ostrvske štampe na grčkom jeziku iz prve polovine 20. veka, kao i literatura koja se odnosi na društveno-ekonomski okvir istog perioda. Od kolonijalnog perioda nadalje, kiparska kultura je prihvatila javni koncert kao dominantno sredstvo za predstavljanje muzike i razvila stabilnu institucionalnu osnovu za zapadnu umetničku muziku, zajedno sa svojim komercijalnim sredstvima, uključujući muzičke instrumente i zvučne uređaje. Uzimajući u obzir komodifikaciju kao jednu od početnih karakteristika kapitalističkog načina proizvodnje, ovaj rad nastoji da identifikuje načine na koje se muzička aktivnost u kolonijalnom Kipru prilagođavala pojmu komercijalne vrednosti, postavljajući tako čvrstu infrastrukturu koja mu je omogućila da uđe u kapitalistički sistem robne razmene.

Ključne reči: Kipar, muzika, britanski kolonijalizam, kapitalizam, komodifikacija 